\author{
Ana Njegovanovic, \\ Freelancer, \\ Croatia, Zagreb
}

\title{
NEUROLOGICAL ASPECTS OF FINANCE, TRANSMITTERS, EMOTIONS, MIRROR NEURONAL ACTIVITY IN FINANCIAL DECISION
}

The aim of the research is to analyse neurological aspects for investment decisions making process, which is a result of complex neurophysiological processes, provides constant revaluation of the statistic information about the problem, balancing of various emotional aspects and weighting of many factors' importance. The study contains wellgrounded generalization and structuring of the scientists' global scientific heritage regarding the explanation of the mechanism to connect the financial and emotional grounds in the investment decisions making process. The article consists of four parts each of which deals with the study regarding the specific behavioural aspects of the economic choice. The author describes the neurological nature to form the signal for the economic decision-making process, logical order of prediction and selection, psychoneurological mechanisms to define the levels and the expected benefit and risk ratio by the economic entities as fundamental categories of modern microeconomic theory, in the first part. The second part of the article deals with the investigation of neurological mechanisms, as a result of which emotional factors (excitement and disappointment, pride and discomfort, feelings of regret, fear of suffering losses, greed, risk, fear to regret the wrong choice, victory effect etc) provoke investors to make irrational decisions in the investment sphere, negate common sense and logic. The third part of the article deals with the role of neurotransmitters (small endogenous chemical messengers of different types (dopamine, serotonin, norepinephrine), with which brain cells interact through synaptic space) in the financial decision-making process. The fourth part of the article describes the neuron resonance phenomenon, which explains the empathy, formation of the reliable relations of customers and partners in business. This phenomenon is caused by the action of mirror neurons (brain cells that react when a person performs a certain physical movement and also observing how the other person does the same, are responsible for imitation, awareness and understanding of the actions, intentions or emotions of another person), which make one of the most significant inventions in the neuroscience.

Keywords: neurotransmitters, financial decision making, mirror neurons, empathy, neuroscience signals of the decision.

Introduction. The financial decision-making process has been a challenge for researchers, including psychology, business management, or economics for the past year (Bertrand, Mullainathan \& Shafir, 2006). Here are some questions in this complex area: why people make certain choices when faced with equal opportunities or why human economic behaviour changes when there are clear rational models. Financial decision-making can be observed in the real world and studied by studying many variables, such as risk, insecurity or limited rationality (Kahneman, 2003). The prospect allows us to deeper, more thoroughly analyze this phenomenon and connect it with emotional and physiological approaches (Hsu et al., 2005).

Feelings and emotions can play a key role in determining our economic behaviour (Rick \& Loewenstein, 2008), as well as our ability to manage emotions in a given context (Gross \& John, 2003). Research in psychological and neuropsychological sciences (Davidson et al., 2000) investigate how people address their need to effectively manage a multitude of emotional incentives that appear in certain situations. Such cognitive and effective regulation is key to achieving satisfactory economic outcomes and influences our daily life.

In the limbic brain, there is a key neural domain that causes negative emotional reactions such as fear 
(amygdala). This neural area is located within the temporal limbs of both hemispheres, and its links fall into parts of the neocortex, such as the orbitofrontal region or the ventromedial prefrontal cortex, the front cingular cortex, the insulins, and other subcortical cores, such as talamus, basal ganglia, or hypothalamus. these areas or circuits that link them include lack of social decision-making (Adolphs et al., 2005). These areas also regulate various forms of empathy and, in the event of any neuronal damage, we may lose our ability to recognize the emotions and thoughts of those around us.

Decision making encompasses a number of functions through which motivation processes contact with action-selection mechanisms to express one outbreak of behaviour. The research on cognitive neuroscience has expanded over the last 15-20 years, starting with a revitalized interest in the role of the ventromedial prefrontal cortex and its interrelated circles as a long-term optimization of decisions (Bechara et al., Damasio, 1994) but is now manifested in the field "neuroeconomics" (Glimcher et al., 2008).

Neurophysiological research enables understanding the functions of the midbrain dopamine neurons with the application of quantitative models of their role in learning and decision-making in uncertainty (Schultz, 2006, 2008). Brain imaging (FMRI) in decision making involves model parameterization that interprets changes in the synthesis of blood oxygen level (BOLD) level in terms of (phase and tone) activity of midbrain dopamine neurons and their limbic, striatal and cortical projection structures (D'Ardenne et al., 2008; Knutson \& Wimmer, 2007; O'Doherty et al., 2007).

Knowing and recognizing sources of negative emotions (fear) leads to the formulation of the hypothesis of "somatic markers". Namely, the function of neurological structures and psychological (cognitive-emotional) mechanisms is united. This means balanced movements between perceptions and emotions in order to make decisions that result in adaptive behaviour, whether their nature is social or economic.

Revolution in the science of emotions has emerged in the last decades with the potential to create a paradigm shift in decision theories. Research reveals that emotions are powerful, pervasive, foreseeable, sometimes harmful and sometimes useful decision makers. In various areas, important laws appear in the mechanisms through which emotions influence judgment and choice.

Current events are mapped or labelled in our minds according to the emotional consequences we had in the past. The basic mechanism includes what can be called somatic markers-physiological reactions that accompany previous emotional significant events that stretch back into our individual history. In this way, the emotion is able to fulfil the vital role of information action (including the processes of attention and perception) very quickly and largely out of consciousness. Evidence supports the view on the existence of a continuous exchange between the brain network associated with feelings (for example in the amygdala) and conscious thoughts (for example in the prefrontal cortex) and the existence of complexes of two-way communication relationships between conscious and unconscious processes. It is wrong to look at this as a double system conflict - as if a struggle between emotional and rational creatures is taking place in us. In essence, cortical higher-order functions, allowing reflection and complex analytical capabilities that work together, not against emotional unconscious processes.

Results of a new survey. UCLA (University of California) on "Activity of Mirror Neurons Predictions in Moral Dilemmas" of how people are likely to avoid harming others when faced with moral dilemmas, research results are published in Frontiers in Integrative Neuroscience, 2018. The study confirms that the actual concern about the pain of other people's causal role in the judgments of moral dilemmas. Mirror neurons are one of the most important discoveries of neuroscience These are brain cells that act simultaneously when someone performs an action or simply when someone else performs the same action by playing a vital role in how people learn through mimicry and feel compassion for others. They are responsible for a phenomenon called a neural resonance.

Dr Marco Lacoboni said, "It would be fascinating to see if we can use brain stimulation to change complex moral decisions by affecting the number of concern people experience for others 'pain," It could 
provide a new method for increasing concern for others' well- being.

The open door is an insight into the theoretical models of empathy that have influenced the academic and public concepts of complex social skills. Questions related to empathy: (1) shared neuronal activation and can be interpreted as evidence for simulation empathy accounts; (2) the causal connection of empathy with our assumed mirror neuron system; and (3) the question of whether empathy increases result in better moral decisions and behaviours.

Literature review. 2005 was marked by the first study on the role of neurotransmitters in financial decision making. Neurotransmitters in financial decision making give people who are in positions of business particularly in the stock market business. The initial research was a "neuronal basis for taking risks", (Kuhnen \& Knutson, 2005) at Stanford University, USA. Emotional intelligence and complementary psychosomatic attribute as a person have a different aspect of the investor's behaviour.

Empathy has many different definitions and descriptions - and this is a somewhat infected area of social neuroscience (Batson, 2011). However, several sociological neuroscientists have suggested that the definition requires a partial, isomorphic division of the feelings of another person to be classified as empathy (Bernhardt \& Singer, 2012, Decety \& Lamm, 2006, Decety et al., 2012, Gonzalez-Liencres et al., 2013 , Singer \& Lamm, 2009). From the aspect of social neuroscience, this interpretation is mainly based on the fact that the Al and MCC brain structures are associated with affective-motive aspects of the pain outside the domain of pain, these areas are associated with the functions of emotional experiences such as common inter-perception and homeostatic regulation (Medford \& Critchley, 2010).

To understand the neuropsychological mechanisms of empathy is not enough to focus on its affective components. Numerous studies have consistently shown that motor and cognitive functions play an important role in stimulating and modulating empathy. For example, observing someone else who caught a fingerlock or fingernail (Jackson et al., 2005, Jackson et al., 2006), getting a hand in hand or acupuncture (Avenanti et al.) It has been shown that (Cheng et al., 2007, Lamm et al., 2007b, Perry et al., 2010) cause "resonance motors" processes, which in turn can cause an affective response to the pain of others. Especially early but influential models of empathy have already suggested the concept of narrow perceptive action in the brain and the automatic resonance of the engine that emerged from it, as a core reminder of empathy (Preston and de Waal, 2002). Likewise, the observation of others that touches deals with our somatosensory system, apparently enabling us to encode the affective properties of indirectly perceived touch (see Bufalari and lonta, 2013; Keysers et al., 2010 for reviews). In the cognitive domain, the ability to deliberately adopt the perspective of others and to imagine their feelings, even without direct observation, can be equally strong inducer of affective responses (Jackson et al., 2006: Lamm et al., 2007a) and (Hein et al., 2010, Hein et al., 2011). This capacity mainly grants cerebral structures associated with mind theory and mentalization, such as medial prefrontal cortex, and temporoparietal connection (Shamay-Tsoory, 2011), i.e. processes that are primarily engaged when they reflect on nonaffective mental states of others.

The conclusion suggests that mirror neurons are the reason why we can sympathize with others. Moreover, the presence of mirror neurons in the monkeys suggests that their function is "firmly wired", leading to the suggestion that we are predestined to resonate with the emotions of others "because of our neural mirrors." The prevalence of such assumptions in media discourse was certainly inspired by some non-critical popular science books (Bauer, 2006, Ramachandran, 2011), but also earlier publications of social neuroscience scientists linking the two phenomena quite liberal but without much evidence. Yet such an attitude is problematic: on the one hand, there is no empirical support, on the other hand, has wide, but misleading implications for our general understanding of empathy.

Neuroscientific signal of decision. To explain investment decisions, financial theorists are called on two opposite metrics: the expected reward and risk. Progress in the spatial and temporal resolution of brain capturing technology allows investigators visualization of changes in neuronal activation before 
financial decisions. Research using these methods shows that although ventral striatum plays a role in representing the expected reward, insula can play a more prominent role in representing the expected risk. Accumulating evidence also suggests that previous neuronal activation in these areas can be used to anticipate upcoming financial decisions. These studies imply prediction of choice and physiologically limited decision theory.

One strategy is to break the complex phenomena into the component and then reconstruct the phenomenon. This reductionist strategy is successfully applied to problems in economics and neuroscience. In the microeconomics, the "expected value" is the fundamental component of the decision (von Neumann and Morgenstern, 1944). Usually formulated as the size of a desirable outcome multiplied by its probability, the expected value provides a common measure that individuals can assign to different options and then use them to dial between them. Although sometimes concluded based on past-year behaviour, the expected value is originally conceived as if the individual had calculated before the decision. By removing the equation choice and systematically different expectations, investigators can identify the neural correlates of expected values. These neural correlations can be used to predict the choice in separate experiments. An increasing number of FMRI (functional magnetic resonance) studies associated with events have adopted this strategy by changing expectations related to the size and/or value of anticipated monetary stimulus expectations and documenting associated neuronal activation.

The first studies to apply FMRI time resolution to specific visualization of stimulation prediction showed mesolimbic activation that emerged before the stimulus outcomes. One study of mixed gambling found greater Mesolimbic activation for gains than losses but did not notice the difference in activation during the anticipation of incentives in relation to the outcome (Breiter et al., 2001). In the second study, the reaction time was determined by detecting increased ventricular striatal activation (including the accumbens core) which is proportional to the size of predicted gains, but not loss (Knutson et al., 2001). The results of these surveys have shown that the expectation of increasing the size of the financial awards was triggered by ventricular striatum, repeated research using gambling and default time reactions (O'Doherty, 2004, Knutson and Cooper, 2005). Future research with improved time resolution can help address the reason for deviation in the abdominal striatum It should be emphasized that simultaneous inclusion of incentives for reward and punishment enables researchers to equalize and exclude potential anticipatory confusions related to attention, engine preparation, excitement, projection, and learning (Knutson et al. 2005, Yacubian et al., 2006). It is interesting that one study further found evidence that activation of amygdalara correlated with the expected punishment (Yacubian et al., 2006).

Although the role of expected value in decision-making is widely recognized, the financial theory further and separately considers the role of risk (Markowitz, 1952). The risk affects the investment decisions of the people in opposition to the expected prize; Even though people pay to maximize expected awards, they also pay to reduce the expected risk. In the first degree, risk can be modelled as an expected deviation from the expected outcomes (mathematical variance). When the opportunity for a fixed reward ranges from 0 to $100 \%$ probability, the risk is greatest at $50 \%$ probability and therefore changes in an orthogonal way of probability, up to the point of maximum uncertainty. Activation in other regions, including insulates, lateral orbitofrontal cortex and middle brain also increases proportionally to increased risk (Dreher et al., 2006; Preuschoff et al., 2006). From these regions, it shows activation associated with uncertainties in other tasks involving money (Critchley et al., 2001), as well as non-monetary stimuli (Huettel et al., 2005; Grinband et al., 2006).

The financial risk can be framed as potential gains balanced with potential losses. However, increasing risk expectations should lead to greater losses and thus avoid the risk (Slovic et al., 2002). Thus, in a task involving risky and safe financial decisions, ventral striatum activation was highlighted during the study when subjects made risky decisions, although these assays also had higher expected value than safe assays (Matthews et al., 2004). In a similar assignment (for points instead of money), respondents showed 
greater insulin activity during the process involving the punishment of risky decisions that provided for safe choices in the next process, especially in those who are prone to stress (Paulus et al. 2003). In a research designed to imitate aspects of financial investment, researchers investigated the anticipated activation before they made a risky investment (stock selection) or a safe investment (link selection). In addition, risky and safe investments can optimally match the choices of rational participants or not.

We can conclude that progress in brain imaging suggests that individuals use some of the same subcortical cash-handling circuits that they use to handle more tangible goods. Convergent evidence implies the activation of ventral striatum in the presentation of the expected reward and possibly activation of the insula in the expectation of the expected risk. Research also shows that activation in these circles does not only correlate with expectations but also precedes and can promote decisions, perhaps in the opposite direction. Preliminary but promising research and evidence provide evidence of feasibility of financial formulation research using a neuroscientific tool.

Emotions. Emotional neutrality is the concept of removing greed, fear and other human emotions from financial or investment decisions. The goal of emotional neutrality is to eliminate emotions from the process of making objective financial decisions in order to achieve the best possible decision, regardless of the emotions that these decisions might have caused (Investopedia).

One of the ways of thinking thinks the mental decision-making process (or should be) rational: a formal process based on optimization of utility (Pfister \& Böhm, 1991). ("Believe that rationality should be based on the validity of emotional estimates, not on formal coherence")

Rational thinking and decision-making leave little room for emotions (Livet, P. 2010). In fact, emotions are often considered irrational phenomena that can undermine reasoning.

However, there are theories and research focused on the important role of emotion in decision making. Loewenstein and Lerner share emotions when making decisions on two types: those that predict future emotions and those who have directly experienced during deliberation and decision-making. Damasio has formulated the hypothesis of somatic markers $(\mathrm{SMH})$, which suggests a mechanism by which emotional processes can lead (or bias) behaviours, especially decision-making.

Most investors are susceptible to human emotions when making investment decisions, although they are not expressed openly. The items take on a strong position in making investment decisions. It triggers human behaviour that is in line with economic forecasts during the investment. Emotions play an important role in making investment decisions just like any other business decision. Financing behaviour seeks to combine behavioural and cognitive psychology theory with conventional economics and finance, provide explanations for why people make irrational financial decisions. Understanding the emotions point to the importance of investor decision-making in different situations that manifests through levels of insecurity. Positive emotions such as self-confidence, challenge and hope increase the decision-makers' tendency to intensify their commitment while negative emotions cause discomfort and fear.

Loewenstein $(2000$, p. 426) in his research suggests that emotions and feelings in financial decisionmaking "often trigger behaviour in guidelines that are different from those that dictate the weighing of longterm costs and the benefits of different activities." Ownership, prices include weighing long-term benefits (right to share in future cash flows due to capital) and costs (the risk of future cash flows), so we can conclude that the emotions and feelings of the investor affect the stock prices. It is important to note that feelings affecting investor decision making are not necessarily equal to feelings affecting stock prices. Feelings can lead to individual investors making suboptimal decisions about "market forces" investments such as arbitrage. Mehre and Sah (2002), providing theoretical support to feelings affecting share prices by pointing to the influence of price investors.

Fear and greed form the systematic fluctuations that later arise from financial bubbles. Westerhoff (2004), proposed a behavioural model that predicts stock price fluctuation by factoring that strong financial behaviour of retailers stimulates these two emotions. The importance of fear and greed in 
influencing financial behavior points to the neuropsychological processes behind these affective states and their reaction to behaviour.

Psychologists have defined concepts of fear and greed in relation to risk and uncertainty (Biel \& Gärling, 1995). Too much, excessive levels of optimism and excessiveness - potentially caused by underestimating the risks - or excessive levels of personal desires are tied. As Jin and Zhou (2011) show, greed has two main features: first, it involves a strong desire for wealth; Secondly, this includes satisfaction and desire by performing an aggressive action. Jin and Zhou consider greed as one of the possible causal factors behind the financial crisis. Greed influences decision-making because, in order to achieve higher profit goals, it is necessary to assume greater risks (the purchase of toxic assets), which is the ultimate cause of bubble development. In that sense, hormones like testosterone, associated with social dominance and status, encourage greed and aggressive behaviour on the basis of market settings.

The analyses consider the emotions impulsive and irrational and neglect the role of decision-making (Kahneman and Tversky, 1979, Von Neumann and Morgenstern, 2007). In "normative decision theory", economic decision-making is based on a "cold" mathematical budget, and decision-makers are idealized as perfect "rational machines". However, research shows that emotion is one of the most important factors in irrational decision-making (Hastie, 2001, Sanfey et al., 2006). For example, emotions can guide people in making decisions in terms of risk and uncertainty and in terms of intertemporal choices, social decisions and moral decision-making (Loewenstein and Lerner, 2003; Rilling and Sanfey, 2011).

Most of the financial decisions are made in the frontal lobe (part of neocortex). The frontal lobe includes parts involved in decision-making processes such as anterior insula, medial prefrontal cortex and nucleus accumbens. The frontal lobe area is the center of the brain responsible for reflecting on the higher levels. This includes solving problems, including thinking, making decisions, judgments, drawing close plans, and far-reaching future. Nucleus Accumbes is a human center for pleasure. If an investor tries to gain a profit from a particular investment and ultimately will get it, the nucleus accumbens will light up by scanning the brain fMRI. However, as soon as the gain is recognized, the activity at the pleasure center is stopped. If an insula takes action that would calm a too excited center for pleasure, it can result in non-investment. If the CEO of the company - the executive brain - Prefrontal cortex - who manages these forces: Center for Pleasure (Nucleus Accumbes) and Risk (Insula). If the risk concern turns into fear of loss then the center of fear - Amigdala is activated. This can lead to a decision not to invest. Prefrontal Cortex is a mediator. This allows us to work according to defined goals (it is stated that an individual defines it as good or bad, therefore it is worth pursuing or not.) So, instead of acting solely on the pleasure or fear (emotions) initiated by Nucleus Accumbes or Anterior Insula, we could give Prefrontal Cortex has the opportunity to resolve the situation more rationally.

Nucleus Accumbes or Insula ("I'm afraid of losing money again. It's better to make a small profit before it's too late, and the stock is turning red again") allows us a change of perspective. Comparisons that reflect (allowing Medial Prefrontal Cortex to do its job) the current situation with previous decisions leads to more rational behaviour.

Research suggests two different and complementary neural systems that are the essence of financial decision-making. Although a network, centered on the ventral striatum, calculating the predicted gain the predicted profit (Knutson et al., 2001; Kable and Glimcher, 2007; Lebreton et al., 2009; Levy et al., 2011); and the other, which includes front isolation, (Paulus et al. (Knutson et al., 2007) and its role in expectation of average financial outcomes Stein, 2006, and Kuhnen and Knutson, 2005; Paulus et al., 2003), as can be seen from the insulin response to price during procurement of goods Samanez-Larkin et al., 2008). Furthermore, the front insula are probably involved in presenting the theologically related concepts of the expected risk (Knutson and Bossaerts, 2007, Mohr et al., 2010).

Wall Street's stereotype trader, the young, aggressive man with testosterone gains confidence and takes great risks. In fact, financial experts are well known for their extensive use of testosterone 
supplements in the hope of improving their competitive advantage, says Amos Nadler, assistant professor of finance at Western University.

Nadler's specialization in neuroeconomics, which combines science and economic theory, isolates the effects of testosterone. In a laboratory simulation of a trade session, his team found that traders who made hormone supplements were more impulsive and helpless and would likely cause inflated property prices. "The testosterone administration has generated larger and longer bladders, causing a high bid and slow incorporation of the underlying asset value," wrote Nadler in a paper recently published in Management Science.

Such scientific experiments provoke the assumptions about what makes a successful investor. Studies exploring the link between financial decision making and hormone, genetics and brain activity are evidence that suggests that our biology and psychology have a significant impact on our financial choices without fully understanding them.

From an evolutionary point of view, the human brain is more wedged to survive in the wild than to maintain the portfolio. Primary emotions surrounding fear, competition, and rewards can spoil rational decision-making. Recent experiments that monitor brain activity by magnetic resonance imaging (MRI) and electroencephalography show that monetization gains the same enjoyment of food, drugs, and sex. Adapting these emotions and impulses can help us limit their harmful potential, says Robert Stammers, director of the CFA Institute. "Once you understand what your temptations and bias are, then you can begin to put the walls around these behaviours."

The classical economy has long relied on the assumption that market participants behave rationally, driven by their own interest in optimal results. But there is a big gap between theory and practice - people behave in seemingly unreasonable ways all the time. Neuroeconomics tries to bridge the gap between economic doctrines and inconsistencies in real life taking into account human emotions. We now recognize the bias that can undermine the impact of the investment.

Neuroeconomics is increasingly able to identify neurological backgrounds for weak choice. Brian Knutson, a professor of psychology and neuroscience at Stanford University, used brain imaging to show how rational thought can overcome the brains of investment decision-makers. In one experiment, subjects were placed in an MRI machine and asked to simulate the stores as they watched their neuronal activity. Knutson discovered that the frontal cortex - part of the brain that is most often associated with decisions until the trader has begun to impose a high profit. Then the blood ran to the core of accumbens, a region associated with pleasure and euphoria. By contrast, overly secure bets were followed by activities in the anterior insula, believed to be the center of pain and anxiety in the brain. Recognizing excessive risky or safe choices back to their neurological roots, Knutson has shown that fear and greed can overtake a more rational brain.

Neurotransmitters in financial decision making. The Virginia Tech Carilion Research Institute investigated the first rapid measurement of dopamine release in the human brain and provided preliminary evidence that a neurotransmitter could trace the movement between brain cells while the subject expresses the behaviour of decision-making,

"The experiment measured the release of dopamine while the participant made investment decisions in stock market trading. The results showed that dopamine pathways change market value," Read Montague, director of the Human Neuroimaging Laboratory and Computer Psychiatry Unit at the Virginia Tech Carilion Research Institute.

"A stunning discovery was that the dopamine signal was a very good indicator of market value and in many cases a good predictor of future market changes," said Kenneth Kishida, a postdoctoral associate of the Human Neuroimaging Laboratory and leading author of the report. The choice that was expressed by the subject did not always correspond to excessive brain chemistry.

The study was published in the Public Library of Science, PLoS ONE, in the article "Sub-Second 
Dopamine Detection in Human Striatum", Kishida; Stefan Sandberg, senior associate of psychiatry and behavioral sciences and pharmacology at the University of Washington, Seattle; Terry Lohrenz, Assistant Professor at the Neuroscience Department, Baylor College of Medicine; Youssef Comair, Professor and Head of Neurosurgery Division, American University of Beirut, Lebanon; Ignacio Saez, assistant at the Virginia Tech Carilion Research Institute; Paul Phillips, Associate Professor, Department of Psychiatry and Behavioral Sciences and Pharmacology, University of Washington, Seattle; and Montague, senior author.

Researchers have adapted their sensors to the existing technology used for functional brain mapping during surgical implantation of deep brain stimulation devices. "Stimulation of deep brain is commonly used to treat Parkinson's disease," Montague said. "Also research is being explored for the treatment of other neurological disorders and can open new ways for the technology we have developed."

Impulsive people have a strong urge to act without thinking. Sometimes it is considered positive, but impulsiveness is also widely present in clinical disorders such as ADHD, drug dependence, mania and antisocial behaviour. Contemporary research has begun to greatly affect the disclosure of brain mechanisms based on impulsive behaviour with a prominent focus on limbic cortico-striatal systems. Thus, we gain insight into the understanding that impulsivity is a multiple behavioural behaviour involving nerve and psychologically different elements.

Serotonin has long been associated with social behaviour, but its precision involved in impulsive aggression was controversial. Although many have assumed the link between serotonin and impulsivity.

Serotonin has long been involved in mood disorders and anxiety. However, researchers at the Danish Research Center for Magnetic Resonance have found that blocking a specific serotonin receptor type 5HT2A has made it less likely that people will take risky decisions and reduce activity in the frontal cortex when they lose what they consider to be low in a gambling task.

"Serotonin 5-HT2A receptor is largely exciting and widely distributed through the cortex," Macovean emphasizes. "When participants play the task of gambling and measure brain activity, we have seen the general effect of brain loss, a network involving a ventral lateral prefrontal cortex and a middle prefrontal cortex, but when we blocked the 5-HT2A receptor using a drug called ketanserin, we saw a decrease in activity in the subgroup of that network, in the media prefrontal gyrus. "

Macoveanu claims that these systems are involved in risk aversion - and serotonin is important because it helps us measure those risks. "Blocking this receptor has caused a risk aversion to healthy subjects even in low-risk activities," Macovean said. "And there could be broad implications for understanding the risk in people with mood disorders and anxiety."

Ann Graybiel, a researcher at the Massachusetts Institute of Technology and a member of the Dana Alliance for Brain Initiatives, has been studying the role of basal ganglia in learning and decision-making for decades. Her lab examines the neural circuit that connects basal ganglia with neocortex through the limbic system. Our emotions can blur or improve our decision-making ability, depending on the situation and the way we feel it.

"The brain has the desire to be optimal, to help us make optimal choices," says Ann Graybiel. The emotion is very powerful and has a profound effect on how we make decisions. "

Her lab continues to study this limb circle to better understand how emotions and potential mood disorders and anxiety play a role in weighing the risks and rewards of making decisions. And she notices that this interesting limb circle is not only stimulated by dopamine, but also by special serotonin receptors.

"Serotonin has the power to deeply affect those circles, just as dopamine," she says. "It becomes increasingly clear that we need to look after dopamine and serotonin to understand how to make decisions, especially how to make decisions when emotions are involved. It is a very exciting time."

Dopamin was involved in risk decision-making and gambling addiction, but the exact mechanisms that are the basis of this influence remain partly inadequate. 
Risk-based decision making is an important area of research on a combination of economics, psychology and neuroscience. Although the known neural substrate, however, the precursor role of the dopamine neuromodulator remains unclear. Its importance is evident in the usual clinical observations that dopaminergic drugs are associated with compulsive gambling in Parkinson's patients (Molina et al., 2000) and increased risk for people (Norbury et al., 2013) and animals (St Onge and Floresco, 2009; Stopper et al., 2014).

Scientists have found brain chemistry included in sensory and reward systems crucial to whether people are relieving the pain of financial losses.

"We like to believe that we all have the free will and make the decisions we want, but that's not so easy," said Julio Licinio (Molecular Psychiatry). "Many people have the predestination to make certain types of decisions."

For a study, a team of researchers who led Hidehiko Takahashi from the Kyoto Medical School of Medicine in Japan reviewed the brain of 19 healthy men with a positron emission tomography scan after completing the gambling task. The experiment showed that a neurotransmitter or chemical messenger, called norepinephrine or noradrenaline, was the central response to the loss of money. Those with low levels of norepinephrine transporter had a higher level of a chemical substance in the key part of the brain - which led to less excitement and less susceptible to the pain of the loss of money, researchers discovered. People with higher levels of the transporter and therefore a lower level of norepinephrine or noradrenaline have what is known as "loss rejection", where they have more pronounced emotional responses to a loss versus gain.

Aversion of losing can vary widely among people, the researchers explained. While most people will only invest two rounds of gambling, if it was possible to win more than they could lose, people with a corrupt decision show a reduced susceptibility to financial loss. Averts of losing can vary widely among people, the researchers explained. While most people will only invest two rounds of gambling, if it was possible to win more than they might lose, people with a corrupt decision show a reduced susceptibility to financial loss. "There is also a need to investigate whether noradrenaline transporters also increase in brain regions traditionally associated with decision making and emotional aspects of aversion such as prefrontal cortex and amygdala."

Mirror neurons can be defined as a class of neurons that react when a person performs a particular physical movement and also when observing another person doing the same. They are subject to imitative action and awareness and understanding of another person's actions, intent or emotion. It has been found that people with autism have a lack of neural activity in several parts of the brain (Medical Dictionary).

A neuron located in a cerebral cortex that is active when performing some work or when someone is testifying that others perform the same action and whose function is considered to be involved in language acquisition and the ability to empathize (Medical Dictionary).

Mirror neurons are a certain kind of neurons (brain cells) that are equally active when we are doing the activity or observe that someone else performs this activity. For the first time, they were discovered in the brains. It has been shown that mirror neurons play an important part in empathy, our ability to feel the happiness or the pain of other people. Research has shown that their activity envisions moral choices involving others.

The empathy phenomenon has opened new insights into theoretical models of empathy and has attracted attention in the area of social unhappiness. The common issues associated with empathy are: (1) shared neuronal activation and can be interpreted as proof of simulation empathy; (2) the causal connection of empathy with our assumed mirror neuron system; and (3) whether increasing empathy will result in better moral choices and behaviours.

One of the main conceptual discoveries of Singer $T$ is "studying the seeds" which was probably one of the reasons for the impacts that empathy carries similar neural networks as well as the direct experience 
that emotions show empathy. By confirming similar work in the field of nausea (Wicker et al., 2003), the research has shown that anterior insular (Al) cortex and anterior midcingulate cortex (aMCC according to Vogt, 2005 but in some studies and most of the initial workings as the front cingular cortex ) are activated when we observe the pain of others. This evidence has confirmed many later types of research, as documented by meta-analysis based on images and coordinates, which are quantitatively integrated and summarize available data (Fan et al., 2011, Lamm et al., 2011).

We are able to understand and share the emotions of others (partly) by treating them with their own emotional system. This also prompted interpretations that set up processes such as simulation and selfprojection in the center of empathy - mechanisms of empathy that were already suggested before the availability of functional neuroimaging evidence (Gallese and Goldman, 1998). In social knowledge, simulation and self-projection have been interpreted several times as the fundamental mechanism of mentalization with respect to other beliefs, intentions or thoughts (Goldman and Sebanz, 2005, Mitchell, 2009).

Empathy is associated with different definitions (Batson, 2011). However, the definition that requires a partial, isomorphic division of the feelings of another person is classified as empathy (Bernhardt and Singer, 2012; Decety and Lamm, 2006; Decety et al., 2012; Gonzalez-Liencres et al., 2013; Singer and Lamm, 2009 ). From the point of view of social neuroscience, the interpretation is mainly based on the fact that the Al and MCC brain structures are associated with the affective-motive aspects of pain outside the domain of pain, these areas are associated with emotional experiences such as common interception and homeostatic regulation (Medford and Critchley, 2010). To understand the neuropsychological mechanisms of empathy, it is not enough to focus on its affective components. Research has shown that motor and cognitive functions play an important role in stimulating and modulating empathy.

How does Morgan Stanley develop empathy in his financial industry? "Empathy is an understanding of what others feel, either because you've experienced it yourself or are actively trying to put it in your shoes. Empathy allows you to build trust with your clients - and this is the most exquisite and inadequate part of every job in the professional industry.

People who start their career tend to think that finding answers is the most important part of the job. But while we are dealing with solutions, finding the right solution is often not what keeps us back. Experience has taught me that if my client says the problem, we will always come up with a thoughtful response. The real challenge is taking the client to tell you the problem.

If he did not ask me to compete for the task of an existing client, this was usually not because the client did not meet me either because I was not capable. I missed the job because the client never gave a bullet to solving the problem. Or the client did not think he called or had not enough confidence to share what he was thinking about. The key to winning a business is to take the client to trust or you just love to tell you which issues are worrisome.

Building a trust relationship can take years, but pays dividends. For years I have worked with a single customer on the merger and acquisition concept that has never been achieved. But during that time I gained client trust because I listened and was trustworthy. This customer, United Parcel Service, ultimately has given our company the leading investor role in the largest initial public offering in history.

So how do you build client trust like this one? You have to focus on listening. And I watched two kinds of listeners: those who listen and listen. Call the former encyclopedia and the latter Empathizer. The encyclopaedia is listening waiting to stop and try to get acquainted with the knowledgeable client; leaves a meeting proud of the wisdom or advice he has given him. Empathizer listens to the understanding of the questions, asks questions to "remove the arch" and to make the client comfortable and ready to share the real problems. Empathizer leaves a meeting with a client seeking help on a particular task"

In a complex theme of empathy and morality, perhaps, it might end with the words of Jim Runde, Morgan Stanly (the world's most famous global bank). "The goal is to develop our role in relationships 
from clients from providers to trusted counsellors," Experience has taught me that if my client says the problem, we have enough smart people working in a collaborative environment to always come up with a thoughtful answer. The real challenge is taking the client to tell you the problem. "That requires trust and confidence only develops if bankers can put in client shoes. That's compassion. The round has developed empathy with clients by asking open questions and listening to the answers. "Only when you and your client click on a personal level, and the client you like, can you build real trust. Almost all the deals I won during my career were because the client entrusted me to me."

Instead conclusion. Financial decision-making is the result of complex neurophysiological processes that include, among other things, permanent re-evaluation of statistical information on the problem, balancing of various emotional aspects, and computing very valuable signals that are at the center of contemporary economic thinking. Deciding neuroscience can be expected in the future by providing a number of effective tools to improve financial decision making.

Neuronal approach to financial decision-making (neurofinancing) becomes more apparent with initial research (Hsu et al., 2005; Kuhnen \& Knutson, 2005; Lo \& Repin, 2002) looking beyond the psychological aspects and deeper into the minds of decision-makers. This has created a "more realistic decision-making model that is capable of explaining a wide range of individual economic behaviours" (Vasile \& Sebastian, 2010, p. 726)

A psychological view of decision-making involves some sort of circular reasoning when behaviour is explained by theoretical constructs that are self-contained in behaviour. Neuroscience could provide an alternative to the research of the very origin of behaviours within the neural structures of the brain.

"Our brain is like a neural parliament composed of opposing political parties struggling to manage the state. Sometimes you decide yourself and sometimes in the long run. We are complex beings because we are overwhelmed by many objections and all of them want to be the main "(D. Egleman, neuroscientist, Stanford University).

Yet we are far from understanding how our brain works. Neuroscientists estimate that human brains are "home to incredible 86 billion neurons with several links that lead from each cellular network in every possible direction, forming a" super-huge cellular network that makes us capable of thinking (ScienceAlert). All of our decisions, including financial, with strong technology development, require interdisciplinary knowledge to face the global new financial industry.

Adolphs, R., Gosselin, F., Buchanan, T.W., Tranel, D., Schyns, P., \& Damasio, A.R. (2005). A mechanism for impaired fear recognition after amygdala damage. Nature, 433 (7021), 68-72.

A. Avenanti, D. Bueti, G. Galati, S.M.Aglioti. (2005) Transcranial magnetic simulation highlights the sensorrimotor side of emapthy for pain Nat. Neurosci, 8, pp.955-960.

Bechara, A., Damasio, A. R., Damasio, H., \& Anderson, S. W. (1994). Insensitivity to future consequences following damage to human prefrontal cortex. Cognition, 50(1-3), 7-15.

Bertrand, M., Mullainathan, S., \& Shafir, E. (2006). Behavioral economics and marketing in aid of decision making among the poor. Journal of Public Policy and Marketing, 25 (1), 8-23.

Biel, A. \& Garing, T. (1995). The role of certainty in resource dilemmas. Journal of Enviromental Psyshology 15 (3), 221-233.

Bernhardt, B. C., \& Singer, T. (2012). The neural basis of empathy. Annual review of neuroscience, 35, 1-23.

Bufalary, et al. (2007). Empathy for pain and touch int he human somatosensory cortex. Cereb Cortex 17 (2007), pp 2553-2561.

Davidson, R. J., Putnam, K.M, \& Larson, C.L. (2000). Dysfunction int he neural circuitry of emotion regulation-A possible prelude to violence. Science, 289(5479), 591-594.

D'ardenne, K., McClure, S. M., Nystrom, L. E., \& Cohen, J. D. (2008). BOLD responses reflecting dopaminergic signals in the human ventral tegmental area. Science, 319(5867), 1264-1267.

Klasen, M., Kreifelts, B., Chen, Y. H., Seubert, J., \& Mathiak, K. (2014). Neural processing of emotion in multimodal settings. Frontiers in human neuroscience, $8,822$.

Hein, G., Lamm, C., Brodbeck, C., \& Singer, T. (2011). Skin conductance response to the pain of others predicts later costly helping. PloS one, 6(8), e22759.

Hein, G., \& Singer, T. (2008). I feel how you feel but not always: the empathic brain and its modulation. Current opinion in neurobiology, 18(2), 153-158.

Gross, J. J., \& John, O. P. (2003). Individual differences in two emotion regulation processes: implications for affect, 
relationships, and well-being. Journal of personality and social psychology, 85(2), 348.

Hsu, M., Bhatt, M., Adolphs, R., Tranel, D., \& Camerer, C.F. (2005). Neural systems responding to degrees of uncertainty in human decision-making. Science, 310(5754), 1680-1683.

Jin, H., \& Zhou, X. Y. (2013). Greed, leverage, and potential losses: A prospect theory perspective. Mathematical Finance: An International Journal of Mathematics, Statistics and Financial Economics, 23(1), 122-142.

Decety, J., Skelly, L. R., \& Kiehl, K. A. (2013). Brain response to empathy-eliciting scenarios involving pain in incarcerated individuals with psychopathy. JAMA psychiatry, 70(6), 638-645

Kable, J. W., \& Glimcher, P. W. (2009). The neurobiology of decision: consensus and controversy. Neuron, 63(6), 733-745.

Kahneman, D., and Tversky, A. (1979). Prospect theory: an analysis of decision under risk. Econometrica, 47, 263-291.

Knutson, B., \& Wimmer, G. E. (2007). Splitting the difference: how does the brain code reward episodes?. Annals of the New York Academy of Sciences, 1104(1), 54-69.

Knutson, B., Wolkowitz, O. M., Cole, S. W., Chan, T., Moore, E. A., Johnson, R. C., \& Reus, V. I. (1998). Selective alteration of personality and social behavior by serotonergic intervention. American Journal of Psychiatry, 155(3), 373-379.

Kuhnen, C. M., Samanez-Larkin, G. R., \& Knutson, B. (2013). Serotonergic Genotypes, Neuroticism, and Financial Choice.

PLoS ONE , 8 (1), 1-9.

Livet, P. (2010). Racional choice, neuroeconomy and mixed emotions. Philosophical transactions of the Royal Society B, 265, 259-269.

Loewenstein, G., O'Donoghue, T. and Rabin, M. (2002). Projection bias in predicting future utility. Working Paper, University of California, Berkeley

Loewenstein, G. (2000). Emotions in economic theory and economic behavior. American Economic Review 65: 426-432.

Loewenstein, G., Weber, E. U., Hsee, C. K. and Welch, N. (2001). Risk as feelings. Psychological Bulletin 127: $267-286$.

Loewenstein, G. (2000). Emotions in economic theory and economic behavior. American Economic Review 65: 426-432.

Loewenstein, G., \& Lerner,J.S., (2003). The role of affect in decision making. In Davidson, K, Scherer, \& H. Goldsmith (eds) Handbook of affective science, pp. 619-642. New York: Oxford University Press.

Mehra, R. and Sah, R. (2002). Mood fluctuations, projection bias and volatility of equity prices. Journal of Economic Dynamics and Control 26: 869-887.

O'doherty, J., Dayan, P., Schultz, J., Deichmann, R., Friston, K., \& Dolan, R. J. (2004). Dissociable roles of ventral and dorsal striatum in instrumental conditioning. science, 304(5669), 452-454.

O'Doherty, J. P., Dayan, P., Friston, K., Critchley, H., \& Dolan, R. J. (2003). Temporal difference models and reward-related learning in the human brain. Neuron, 38(2), 329-337.

O'Doherty JP, Hampton A, Kim H. Model-based fMRI and its application to reward learning and decision making. Ann N Y Acad Sci. 2007;1104:35-53

Pfister\&Bohm (1991). Remarks on the observations on the feeling oft he beautiful and sublime (J.T. Goldthwait,Trans). Berkeley, CA: University of California Press. (original work published 1764).

Portas et al., (2000). The cognitive Neurosciences, The Mit Press, Cambridge, Massachustts, England.

Schultz, W. (2006). Behavioral theories and the neurophysiology of reward. Annu. Rev. Psychol., 57, 87-115.

Steinberg, E. E., \& Janak, P. H. (2013). Establishing causality for dopamine in neural function and behavior with optogenetics. Brain research, 1511, 46-64.

Shamay-Tsoory, S. G., Abu-Akel, A., Palgi, S., Sulieman, R., Fischer-Shofty, M., Levkovitz, Y., \& Decety, J. (2013). Giving peace a chance: oxytocin increases empathy to pain in the context of the Israeli-Palestinian conflict. Psychoneuroendocrinology, 38(12), 3139-3144.

Rick, S. \& Loewenstein, G. (2008). The role of emotion in economic behavior. In M. Lewis, J.M., Hayiland-Jones\& L. Feldman Barett (Eds), Hendbook of emotion, Third edition (pp.138-156), Nova York, NY: Guilford Press.

Sukel, K. (2012). Decision making: Beyond dopamine. The Dana Foundation, Website,17 January, 2012 $81-96$.

Singer, T., \& Lamm, C. (2009). The social neuroscience of empathy. Annals of the New York Academy of Sciences, 1156(1),

Von Neumann, J., \& Morgenstern, O. (2007). Theory of games and economic behavior (commemorative edition). Princeton university press.

\footnotetext{
А. Нежовановіч, фрілансер (Загреб, Хорватія)

Неврологічні аспекти прийняття фінансових рішень: нейротрансміттери, емоції, активність дзеркальних нейронів

Метою дослідження є аналіз неврологічних аспектів прийняття інвестиційних рішень, яке є результатом складних нейросрізіологічних процесів, передбачає, серед іншого, постійну переоцінку статистичної інформації про проблему, збалансування різних емоційних аспектів та зважування важливості значної кількості факторів. Дослідження містить грунтовне узагальнення та структуризацію світового наукового доробку вчених щодо пояснення механізму поєднання фінансового та емоційного підгрунтя при прийнятті інвестиційних рішень. Стаття структурно складається 3 чотирьох частин, кожна з яких присвячена дослідженню специфічних поведінкових аспектів економічного вибору. В
} 
першій частині статті автор описує неврологічну природу формування сигналу для прийняття економічного рішення, логічну послідовність прогнозування та вибору, психонейронні механізми визначення економічними суб'єктами рівнів та співвідношення очікуваної вигоди та очікуваного ризику як фундаментальних категорій сучасної теорії мікроекономіки тощо. Друга частина статті присвячена дослідженню нейронних механізмів, в результаті якого емоційні фактори (ажіотаж і розчарування, гордість і дискомфорт, почуття жалю, страх потерпіти збитки, жадібність, ризик, страх пошкодкувати за неправильний вибір, ефект перемоги тощо) провокують прийняття інвестором нераціонального рішення в сфері інвестування, нівелюють здоровий глузд і логіку. Третя частина статті присвячена ролі нейротрансміттерів (маленьких ендогенних хімічних месенджерів різних типів (дофамін, серотонін, норадреналін), з якими клітини головного мозоку взаємодіють через синаптичний простір) у процесі прийняття фрінансових рішень. $B$ четвертій частині статmі описується фенномен нейронного резонансу, який пояснює емпатію, формування довірчих відносин з клієнтами та партнерами в бізнесі тощо . Цей феномен викликаний дією дзеркальних нейронів (клітини мозку, які реагують, коли людина виконує певний фрізичний рух, а також спостерігаючи, як інша особа робить те ж саме відповідають за імітацію, усвідомлення та розуміння дій, намірів чи емоцій іншої людини), які стали одним з найважливіших відкриттів в галузі нейронауки.

Ключові слова: нейротрансміттери, прийняття фінансових рішень, дзеркальні нейрони, емпатія, сигнали неврології, інвестиційні рішення. 